\title{
Feasibility of Artificial Slope Hazards Identification in Regional Mountainous Highway Using SBAS-InSAR Technique: A Case Study in Lishui, Zhejiang
}

\author{
Zhi Hu ${ }^{1,2} \oplus$, Danqiang Xiao ${ }^{1,2}$, Wei Zhan ${ }^{1,2, *}$, Yang $\mathrm{Yu}^{3}$, Yiqiang $\mathrm{Yu}^{1,2}$, Xin Yan ${ }^{1,2}$ and Chunmei Pan ${ }^{4}$ \\ 1 Key Laboratory of Road and Bridge Detection and Maintenance Technology Research of Zhejiang Province, \\ Hangzhou 310023, China; huzhi0107@sina.com (Z.H.); xiaodq@hhu.edu.cn (D.X.); yuyqfj@163.com (Y.Y.); \\ 11534021@zju.edu.cn (X.Y.) \\ 2 Zhejiang Scientific Research Institute of Transport, Hangzhou 310023, China \\ 3 Ocean College, Zhejiang University, Zhoushan 316021, China; yang-yu@zju.edu.cn \\ 4 Lishui Management Center, Zhejiang Communications Investment Expressway Operation Management \\ Co., Ltd., Lishui 323000, China; panchunmei_cico@163.com \\ * Correspondence: zhanwei@zju.edu.cn
}

check for updates

Citation: Hu, Z.; Xiao, D.; Zhan, W.; Yu, Y.; Yu, Y.; Yan, X.; Pan, C. Feasibility of Artificial Slope Hazards Identification in Regional

Mountainous Highway Using SBAS-InSAR Technique: A Case Study in Lishui, Zhejiang. Appl. Sci. 2021, 11, 8962. https://doi.org/ 10.3390/app11198962

Academic Editor: Daniel Dias

Received: 25 August 2021

Accepted: 24 September 2021

Published: 26 September 2021

Publisher's Note: MDPI stays neutral with regard to jurisdictional claims in published maps and institutional affiliations.

Copyright: (c) 2021 by the authors. Licensee MDPI, Basel, Switzerland. This article is an open access article distributed under the terms and conditions of the Creative Commons Attribution (CC BY) license (https:// creativecommons.org/licenses/by/ $4.0 /)$.

\begin{abstract}
Safety status of artificial slopes is significant for the operation and maintenance of highway to mitigate the risk; thus, slope hazard identification is necessary. In order to realize large-area and low-cost application for regional highway, taking the Longqing Highway (length of $55 \mathrm{~km}$ ) as a case study, the SBAS-InSAR (Small Baseline Subset-Interferometric Synthetic Aperture Radar) technique is adopted to detect the ground deformation and conduct hazard identification based on slope dip, aspect, geological data and historical hazard record. Field survey is carried out to verify the identified potential hazards. Results show that the detected potential hazards are distributed mainly in the areas consisting of granite residual and the Quaternary soil. Six potential hazards identified by the SBAS-InSAR-based method are roughly in accordance with the on-site verification. It is suggested that the SBAS-InSAR technique has the ability to obtain the slope deformation accurately and reveal the safe condition of the slopes. The SBAS-InSAR technique can be suitable for assistance in regional highway slope inspection.
\end{abstract}

Keywords: artificial slope; hazard identification; mountainous highway; SBAS-InSAR; field verification

\section{Introduction}

Slope failures (e.g., landslide, debris flow, and rock collapse) pose a great threat to safety of life and property and highway structures in mountainous area [1], and it has attracted the attention of highway maintenance departments to mitigate slope hazards. As the safety status of highway slopes is affected by many factors such as topography, geology, climate, stabilization work, etc., it is complex and highly uncertain to identify the potential slope hazards. Normally, the ground deformation or deformation-based indexes are used to evaluate the slope stability, via deformation monitoring methods including leveling, triangulation, and GNSS (Global Navigation Satellite System) positioning measurement [2]. Although the accuracy of these methods is high, there are some drawbacks of frequent in situ operation, intensive labor input, and high maintenance cost. In addition, the above methods can only provide point-to-point result; thus, it is possible of information omission between adjacent observation points for linearly distributed highways or railways [3]. Alternatively, with the development of space remote sensing techniques and interpretation algorithms, Interferometric Synthetic Aperture Radar (InSAR) technology can provide wide-range coverage and centimeter level or higher accuracy, which becomes a trend for regional highway slope hazard identification and long-term monitoring [4-6].

For highways, multitemporal InSAR (MT-InSAR) is more suitable than the conventional D-InSAR (Differential InSAR) method, as it can overcome the limitations of spatiotem- 
poral decorrelation and atmospheric disturbance $[7,8]$. The MT-InSAR techniques have been devoted to a series of meaningful explorations in the geohazard identification [9-12], ground deformation monitoring [13-17], bridge deformation monitoring [18,19], and building deformation detection [20], etc. As limited by the spatial displacement gradient, the InSAR is normally suitable for detection of slow $(13 \mathrm{~m} / \mathrm{month})$ to extremely-slow $(<16 \mathrm{~mm} / \mathrm{yr})$ movement [21]. Commonly used MT-InSAR techniques include PS-InSAR (Persistent Scatterer Interferometry) [22-25] and SBAS-InSAR [26-29]. The PS-InSAR method obtains long-term series of ground deformation at the expense of the density of monitoring points in space. Since the differential interferograms generated by the PSInSAR method are all based on the single master image, there may be cases where the interferometric has long temporal and spatial baseline. However, this can reduce the coherence of the data points and result in small number of PS (persistent scatterer) points. The SBAS-InSAR method uses a multimaster image combination method to limit the temporal baseline and spatial baseline of the interferometric pairs to improve the coherence and deformation detection accuracy. It can not only overcome the coherence loss of PS-InSAR due to selecting single master image but also reduce the demand number of SAR data and increase the computational efficiency [30].

In terms of application in highways, Bayer et al. [31] used the SBAS-InSAR method to study the evolution of landslide deformation caused by highway tunnel construction. Zhu et al. [32] investigated the ground subsidence of two highways using SBAS-InSAR method, and the external accuracy was improved from \pm 4 to $\pm 3 \mathrm{~mm}$ by adopting the seasonal model. Zhao et al. [6] studied the landslide susceptibility mapping (LSM) of Karakorum Highway using SBAS-InSAR technology and logistic regression model. By introducing the SBAS-InSAR slope deformation results, the LSM was refined. Recently, Zhu et al. [11] conducted preliminary identification of geological hazards by SBAS-InSAR technique integrated multiple spatial analysis. The visibility analysis was used to remove the influence of geometric distortion of SAR images. Based on the above literature review, most studies focus on large-scale geological hazards within a specific region. However, targeted investigations on the safety evaluation and hazard identification of highway artificial slopes are few using the SBAS-InSAR technique.

Therefore, the feasibility of artificial slope hazard identification for mountainous highways using SBAS-InSAR technique was studied. InSAR-based ground deformation was firstly obtained to determine the deformation abnormal area. Then, the terrain data, geological data, and historical hazard records were introduced to filter out potential slope hazards. The results were validated by field investigation on the Longqing Highway in Lishui, China, and the feasibility of SBAS-InSAR technique in highway slope inspection was discussed.

\section{Study Area and Datasets}

The Longquan to Qingyuan highway, as one section of the G25 national highway, is the main study object in the present study. This highway is about $55 \mathrm{~km}$ in total, from Longquan City, via Chatian, Xiaomei, Huangtian and Zhukou, to Qingyuan County. It is in the southernmost end of Zhejiang Province, adjacent to Fujian Province, as illustrated in Figure 1a. The study area is identified by the $1 \mathrm{~km}$ buffer of the Longqing highway, as shown in Figure $1 \mathrm{~b}$. The area is hilly and mountainous landforms, with an elevation range of $120 \mathrm{~m} \sim 1900 \mathrm{~m}$. The highest mountain of East China is seated northeast of the highway, namely Huangmao Jian (1929 m). As the large elevation difference in the area, its climate difference is also very significant in space. Commonly, the area below $800 \mathrm{~m}$ has a sub-tropical humid monsoon climate, while the area above $800 \mathrm{~m}$ is close to temperate and monsoonal climate. The average annual temperature is $17.4{ }^{\circ} \mathrm{C}$, and total annual precipitation is $1760 \mathrm{~mm}$. The rainy season is mainly from March to June, and it is influenced by typhoon activities. 




(a)

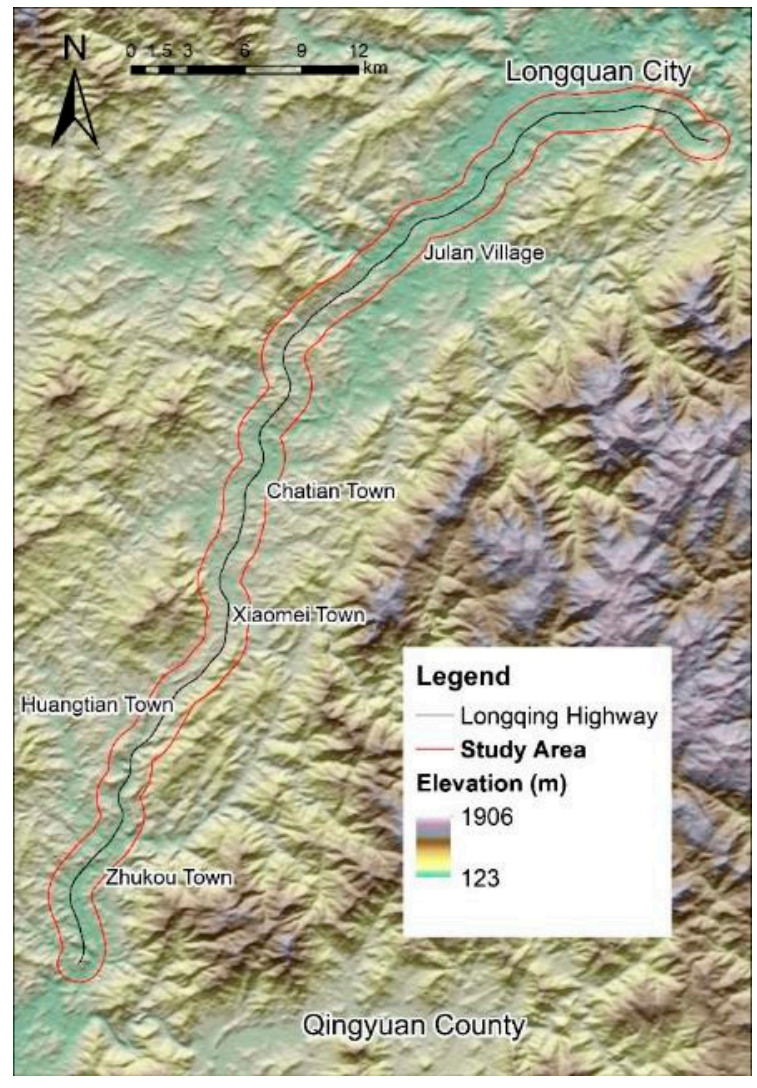

(b)

Figure 1. Study areas: (a) location of Longqing Highway and coverage of SAR image; (b) the STRM 1 Sec $30 \mathrm{~m}$ digital elevation model of the study area.

From a geological point of view, the study area mainly consists of a Holocene formation $\left(\mathrm{Q}_{4}\right)$, five Jurassic formations $\left(\mathrm{J}_{1}, \mathrm{~J}_{3}{ }^{\mathrm{a}}, \mathrm{J}_{3}{ }^{\mathrm{b}}, \mathrm{J}_{3}{ }^{\mathrm{c}}, \mathrm{J}_{3}{ }^{\mathrm{d}}\right)$, and a Devonian formation (AnDch) as shown in Figure 2a. Igneous rock formations formed in the late Yanshanian $\left(\gamma \pi_{5}, \gamma_{5}{ }^{3}\right.$, $\left.v \xi \gamma_{5}\right)$, early Yanshanian $\left(\gamma_{5}{ }^{2}\right)$, and the Indosinian migmatite $\left(\gamma \delta \mathrm{M}_{5}, \nu \xi \gamma \mathrm{M}_{5}\right)$ are also widely distributed in the area. The rock formations are commonly weathered extensively at the ground surface; as a result, the studied slopes mainly consist of loose soil deposits. A total of 84 soil slopes are distributed along the entire Longqing Highway. According to the highway slope management records, there have been a total of 40 small-to-medium-sized cut-slope landslides or embankment washouts from 2015 to 2019 (no hazards recorded in 2018 and 2020), as illustrated in Figure 2b. The historical slope hazards show an obvious spatial uneven distribution mainly within $\mathrm{A}, \mathrm{B}$, and $\mathrm{C}$ three zones. Combining topography and geological conditions, it can be seen that zone B is located in the mountain valley area, and the stratum along the highway is dominated by Quaternary alluvial soil. Moreover, large differences exist in lithology within zone C. The highway slope body is mainly composed of fully-to-strongly weathered layers such as early Yanshanian intrusive granite, upper Jurassic tuff, lower Jurassic sandstone, and lower Devonian schist. The residual materials are caused by the warm and humid climate in southern Zhejiang, and they are generally broken and loose. Coupled with rainfall, slope hazards are more likely to happen within these two zones. 


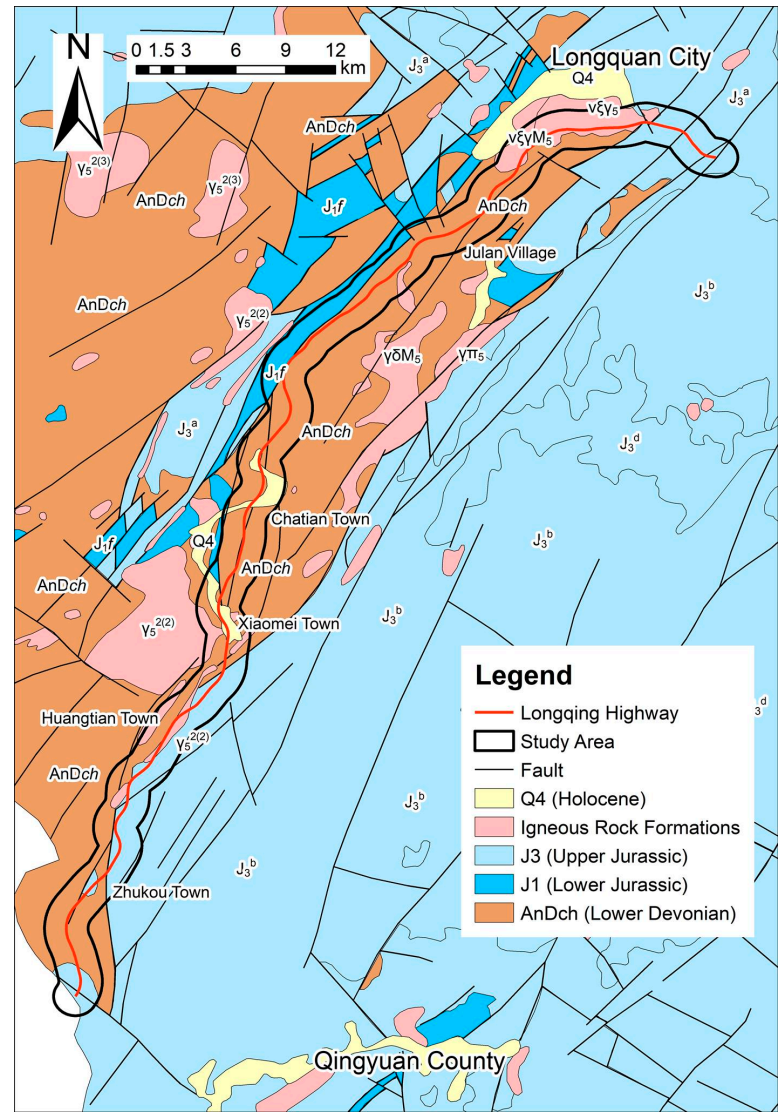

(a)

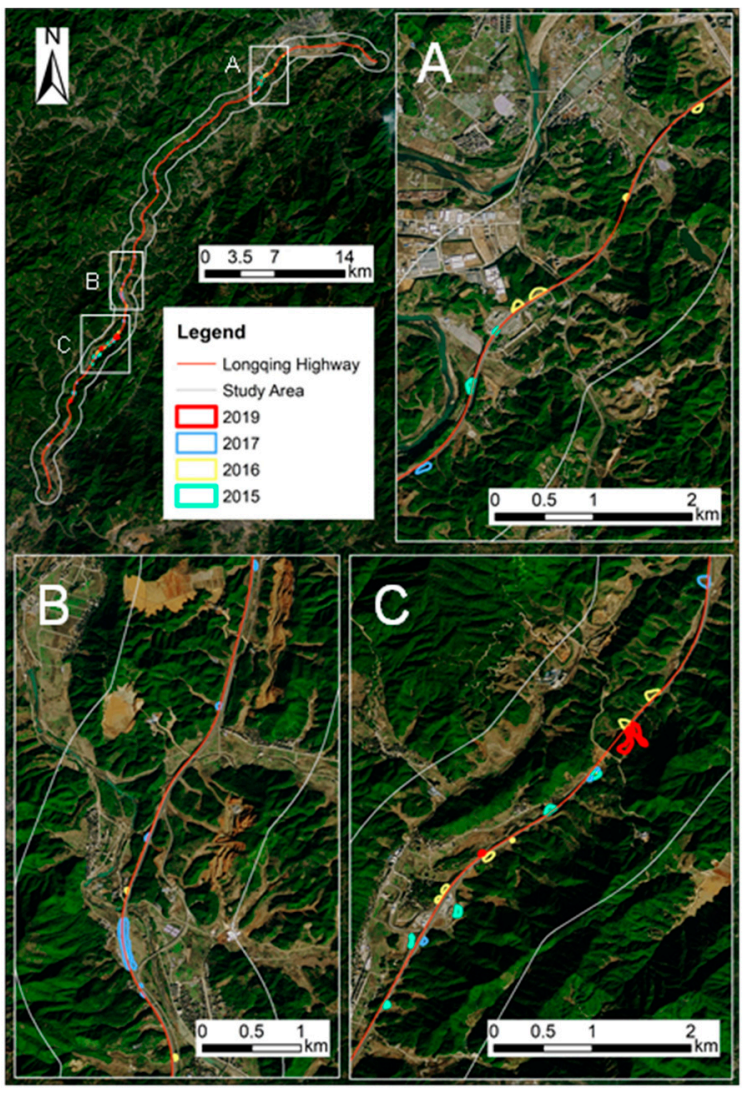

(b)

Figure 2. (a) Geology map for the study area; (b) historical slope hazard records within the study area.

To investigate the slope ground deformation and identify slope hazards along the highway, 30 scenes of ascending Sentinel-1A (S1A) satellite images were obtained from the European Space Agency in this study. The time span is from 8 August 2020 to 5 April 2021 with a time interval of 12 days. The images are acquired in C-band (wavelength of $5.64 \mathrm{~cm}$ ) and generated into Level-1 Single-Look Complex (SLC) products. The imaging mode is the Interference Wide (IW) Mode, the width is $250 \mathrm{~km}$, and the image spatial resolution is $20 \mathrm{~m} \times 5 \mathrm{~m}$ (azimuth $\times$ range). Observation parameters for the images are as follows: path numbers, 142 ; average incidence angle, $43.1^{\circ}$; polarization mode, VV.

In this study, the $30 \mathrm{~m}$ resolution SRTM 1Sec and $90 \mathrm{~m}$ resolution STRM 3Sec DEM data are selected as the external DEM data for master-slave image coregistration and terrain phase removal. Optical remote sensing images were obtained from National Platform for Common Geospatial Information Services (https: / www.tianditu.gov.cn/, accessed on 22 August 2021). The geological map at 1:200,000 scale for the study area was accessed from National Geological Archives of China (http:/ / www.ngac.org.cn/, accessed on 22 August 2021).

\section{Methodology}

\subsection{SBAS-InSAR Techniques}

The SBAS-InSAR method was first proposed by Berardino et al. [30]. The SBAS-InSAR method can extract distributed point targets that maintain coherence within a certain period and further increase the point density. It is very suitable for natural ground deformation monitoring and can achieve long-term, millimeter-level deformation monitoring at the regional scale.

The principle of SBAS-InSAR technology is as follows: First, calculate the time and space baselines of multiscene SAR images covering a certain area in different time periods, 
select the appropriate temporal and spatial baseline threshold to generate the interferometric pairs; then perform differential interferometry processing on the selected master-slave image pairs and conduct the phase unwrapping; finally, phase errors caused by topography and orbit are removed, and the least square method or singular value decomposition (SVD) method is used on the interferogram subsets to estimate the deformation parameters. In actual processing, the method of temporal and spatial filtering is used to remove the atmospheric delayed image to separate the nonlinear deformation. The sum of the estimated low-frequency deformation and this nonlinear deformation is the deformation information of the entire study area.

The SNAP (official open-access software for Sentinel data, developed by European Space Agency) and StaMPS/MTI (version 4.1b, Stanford Method for Persistent Scatterers/ Multi-Temporal InSAR developed by Andy Hooper et al.) were adopted to process the SAR images. The processing flow of SBAS-InSAR method is shown in Figure 3 [33-35]. The small baseline interferograms were first generated by SNAP, and the amplitude dispersion threshold of 0.6 was adopted to preprocess the candidate PS pixels $[5,36]$. Then, phase unwrapping, phase error corrections, and deformation estimation were carried out by StaMPS/MTI.

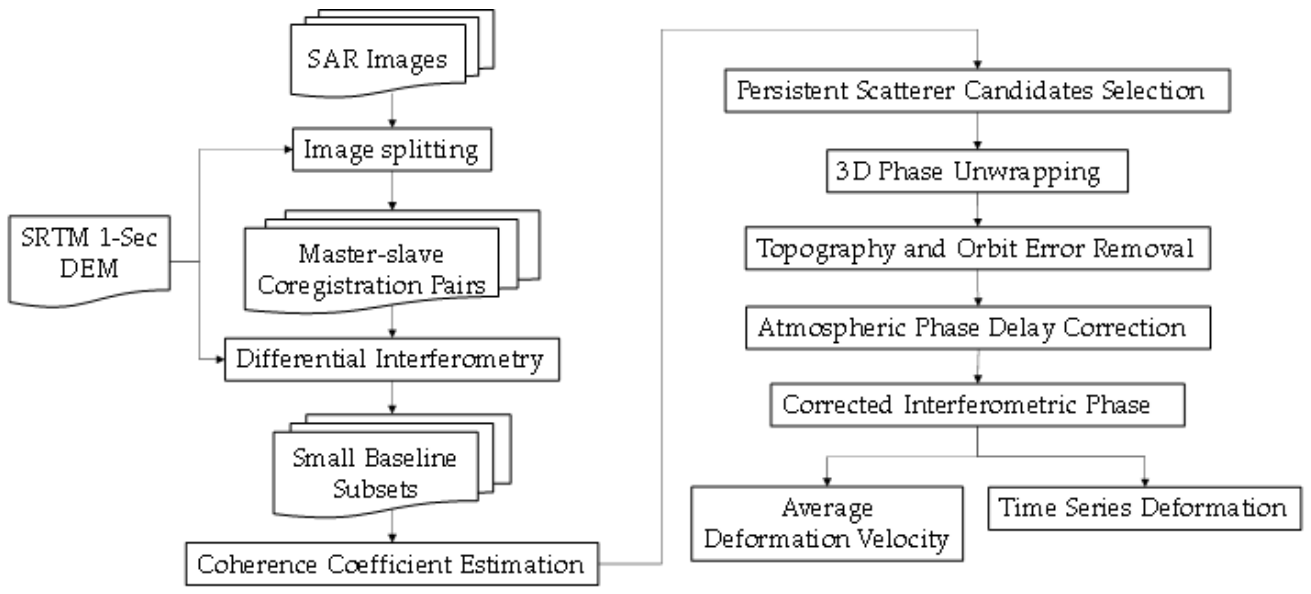

Figure 3. Procedures of SBAS-InSAR method based on SNAP-StaMPS workflow.

Taking the image of 12 November 2020 as the super-master image, the time baseline threshold is set to $72 \mathrm{~d}$, and 90 interferometric pairs can be obtained. The small baseline dataset combinations are shown in Figure 4.

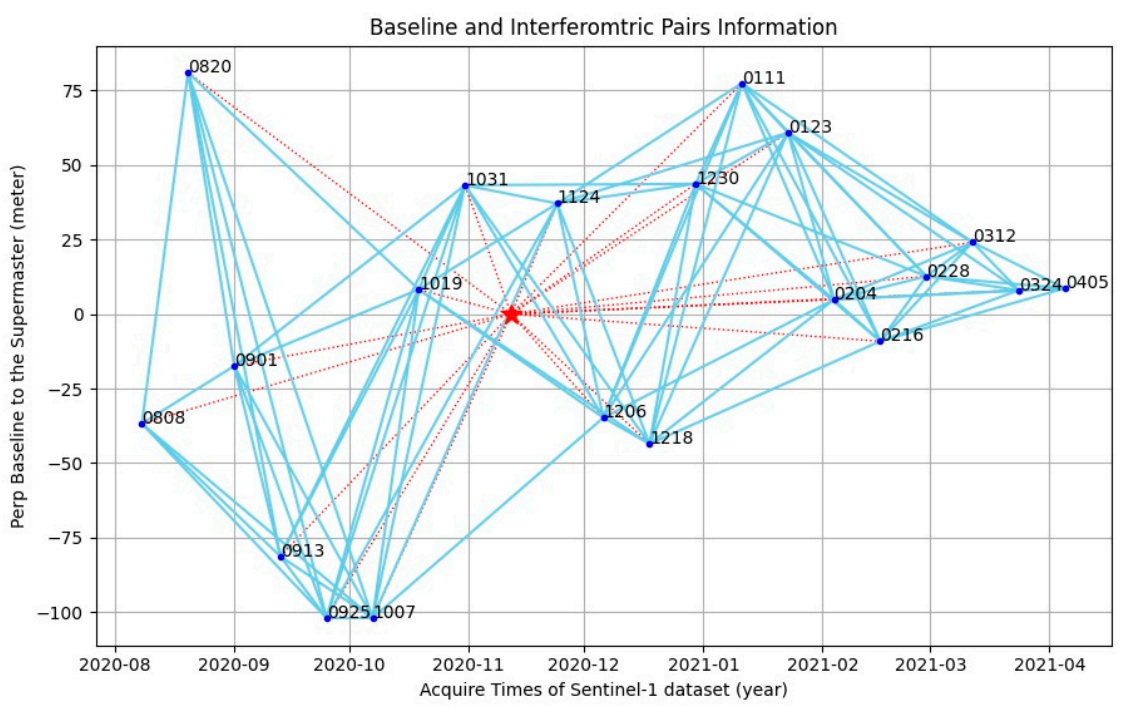

Figure 4. Temporal and spatial baselines of SAR datasets. 


\subsection{Procedure of Slope Hazard Identification along Highway}

Unlike the large-scaled geological hazards, the artificial slope hazards along the highway generally have the characteristics of small scope and scattered distribution. In addition, the highway slope vegetation coverage rate is normally high; therefore, slope hazards in the vegetation coverage area cannot be easily identified. Therefore, in the process of identifying slope hazards along highways, more attention should be paid to information such as terrain slope, aspect, and engineering history to improve the accuracy of judgment. For this reason, the following two steps adopted the research on the identification of potential slope hazard points.

\subsubsection{Interpretation of InSAR Results}

The SBAS-InSAR method is used to process the SAR images to obtain the average annual ground deformation velocity along the highway. When deformation velocity is positive, the ground is moving toward the satellite along the Line of Sight (LOS), and when deformation velocity is negative, the ground moves away from the satellite. Applying a velocity threshold of $\pm 10 \mathrm{~mm} / \mathrm{yr}$, a series of abnormal areas can be filtered out. If the deformation abnormal area coincides with slopes within the highway boundary, this area can be considered as one potential slope hazard candidate.

\subsubsection{Identification of Slope Hazards}

In combination with the slope, aspect, geological condition, optical remote sensing image, and historical hazard records of the study area, potential slope hazards are filtered out through comparative analysis. To reduce the probability of misjudgment, field verification study should be carried out and determine the slope hazards.

\section{Results and Discussions}

\subsection{Interpretation of InSAR Results}

Average ground deformation velocities within the study area are presented in Figure 5. As shown in the velocity map in Figure 5a obtained by SBAS-InSAR method, the deformation velocity of the study area ranges from -58.10 to $78.58 \mathrm{~mm} / \mathrm{yr}$. Most of the area is stable with an average deformation velocity of $5.69 \mathrm{~mm} / \mathrm{yr}$, while the region north of Chatian Town is observed to show an overall movement away from the satellite apparently. It may be due to the regional overall ground surface movement. In the figure, a zoom region at Huangtian Town is presented, and two local abnormal areas can be observed at the bottom left and center of the figure in red color. In the present study, the focus is on the slope along the highway; therefore, only the area A (approximately located on an artificial slope) is taken into consideration in the following analysis.

According to the abnormal displacement shown in the ground deformation velocity map, 22 potential hazards as shown in Figure $5 \mathrm{~b}$ can be initially identified. In addition, the historical slope hazards are also drawn in Figure 5b. By comparing above data, it can be found that the hazards identified in this study are mainly distributed to the south of Chatian Town, which is basically consistent with the spatial distribution of historical hazards. Furtherly, it can be suggested that the granite residual layer and the Quaternary soil layer widely distributed south of Chatian Town are more vulnerable to slope hazards. 


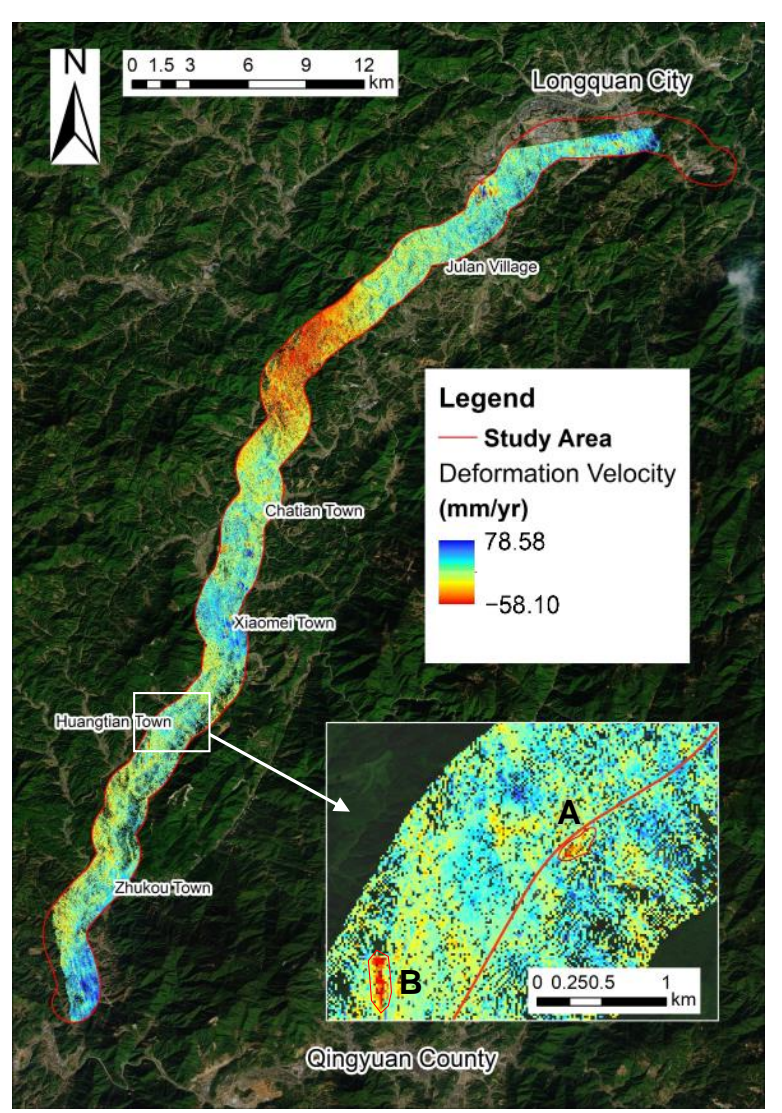

(a)

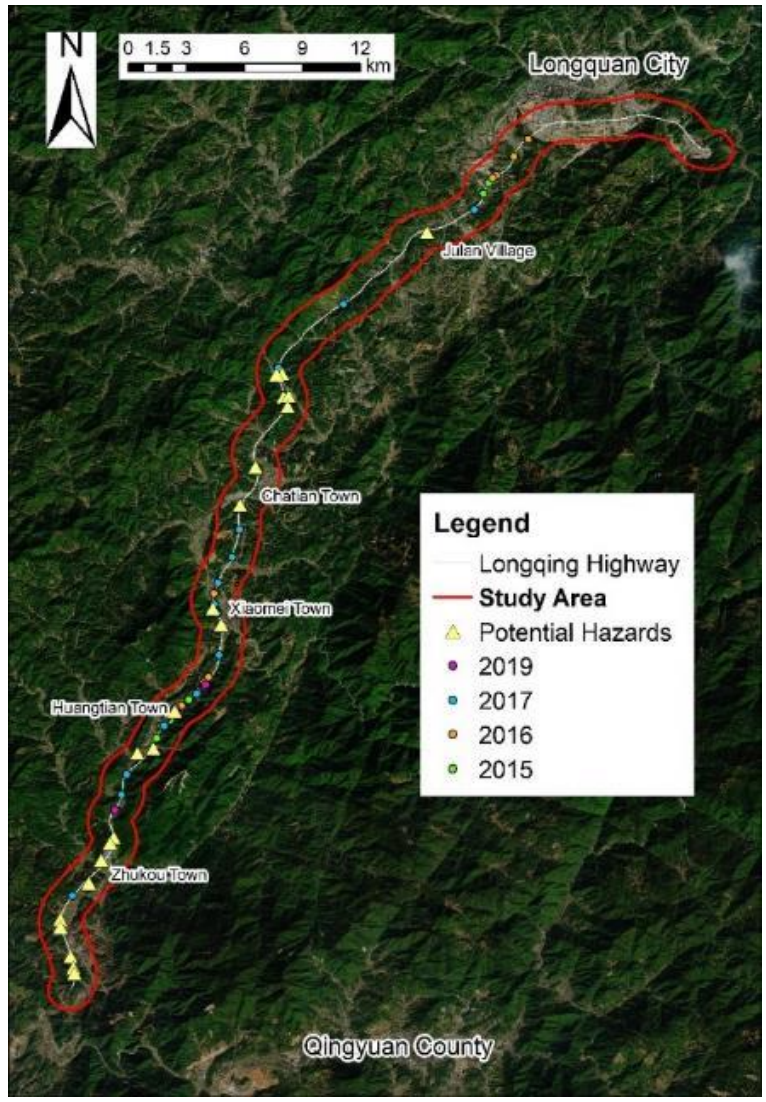

(b)

Figure 5. (a) Average ground deformation velocity of the study area; (b) potential hazards detected based on InSAR results.

\subsection{Identification of Slope Hazards and Field Validations}

According to the procedures of slope hazard identification as described in Section 3.2, the slope and the aspect for the study area are analyzed and introduced as shown in Figure 6. From Figure 6a, the potential hazards are concentrated in the areas with relative high slope value, especially from Huangtian Town to Zhukou Town. Considering the aspect as presented in Figure $6 \mathrm{~b}$, the main reason is that the surface deformation obtained by the InSAR method is a displacement component along the line of sight, rather than the real value. The radar wave incident direction of the Sentinel-1A satellite ascending data used in this study is about $\mathrm{NE}^{\circ} 0^{\circ}$. For slopes with dip direction (about NW350 $0^{\circ}$ or SE170 orthogonal to this direction, it is difficult to judge the actual possible surface deformation by the LOS deformation velocity. Therefore, in this study, the abovementioned situation was excluded for slope hazard investigation.

Based on the above analysis, finally six potential slope hazards (named P1 P6) were identified as illustrated in Figure 7. As seen from the figure, the areas of P3 and P4 are in nearly the same positions where historical hazards occurred. To summarize, the single hazard area is not large and is highly coincident with the highway cutting slope regions rather than natural slopes. 


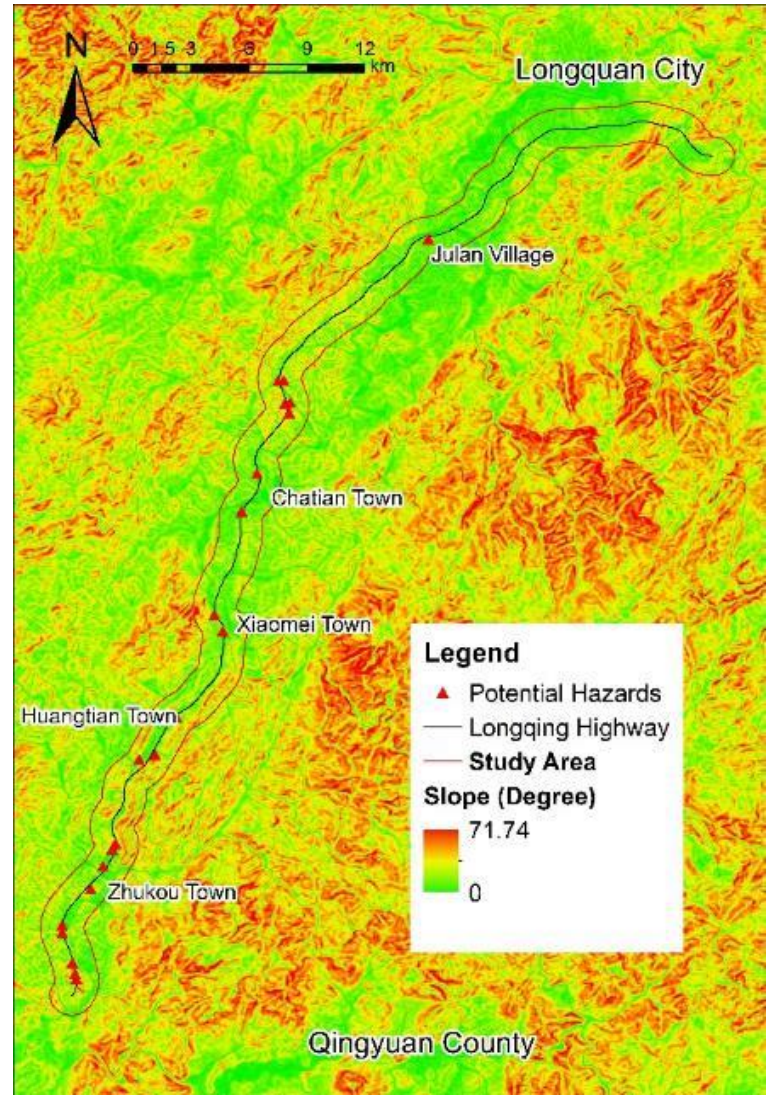

(a)

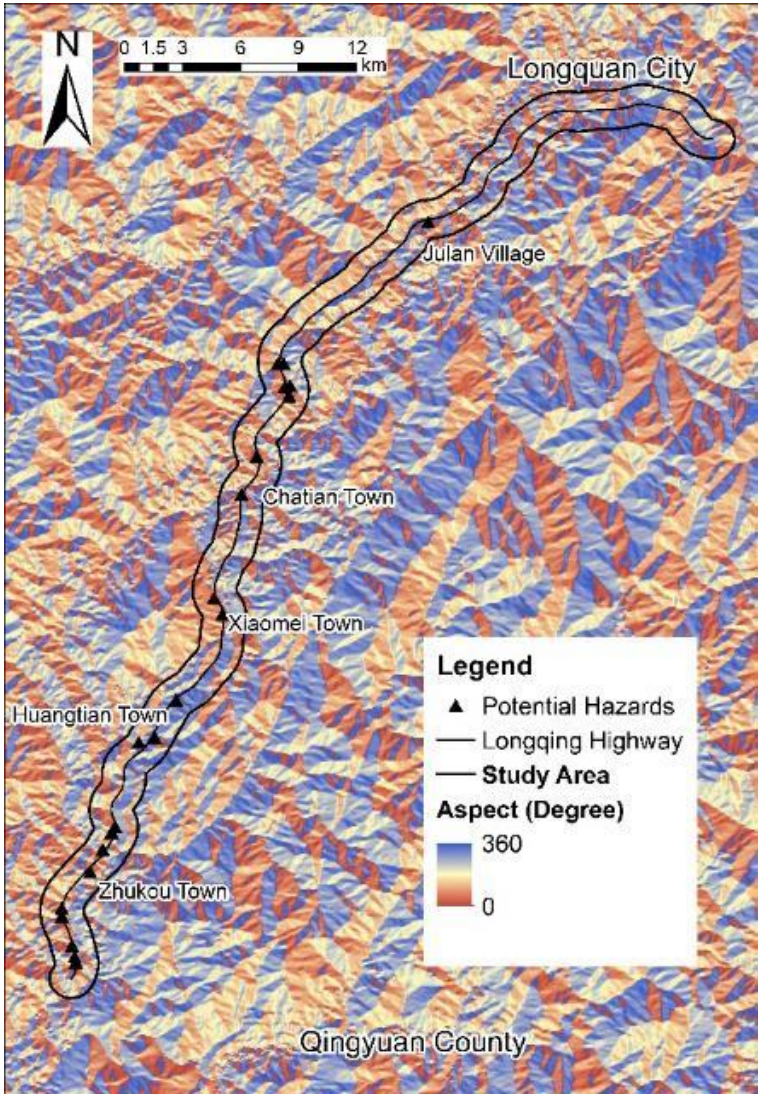

(b)

Figure 6. (a) Slope map of the study area; (b) aspect map of the study area.

To better analyze the potential hazards, annual average deformation velocity and time-series deformation of typical PS points are plotted in Figures 8 and 9, respectively. In Figure 8, the studied PS points are marked and numbered (e.g., ps-4-1 representing the first PS point selected for slope potential hazard P4) consequently. Considering the comparison between different slope, the initial deformation for each PS point is recalculated to zero.

The potential hazard P1 showed obvious deformation on the InSAR results map. The deformation area is mainly located in the south part of the slope, as shown in Figure 8. The deformation evolution of point ps-1-1 indicates that the slope has a continuous downward moving trend during the study period.

The abnormal deformation area of potential hazards P2 and P5 is relatively small (Figure 8), and the time-series deformation of P2 shows more obvious reduction trend than P5.

P3 is located on the cutting slope of the bridge-to-subgrade transition zone, covered with dense natural vegetation. It can be seen from Figure 8 that the obvious deformation abnormal area is consistent with the slope range. Two chosen PS points are located at the center (ps-3-1) and crest (ps-3-2) of the slope, respectively. In Figure 9, the deformation evolution of two positions is both slightly decreasing before 31 December 2020; after the date, the crest remains stable while the center of the slope becomes to move downward apparently. 


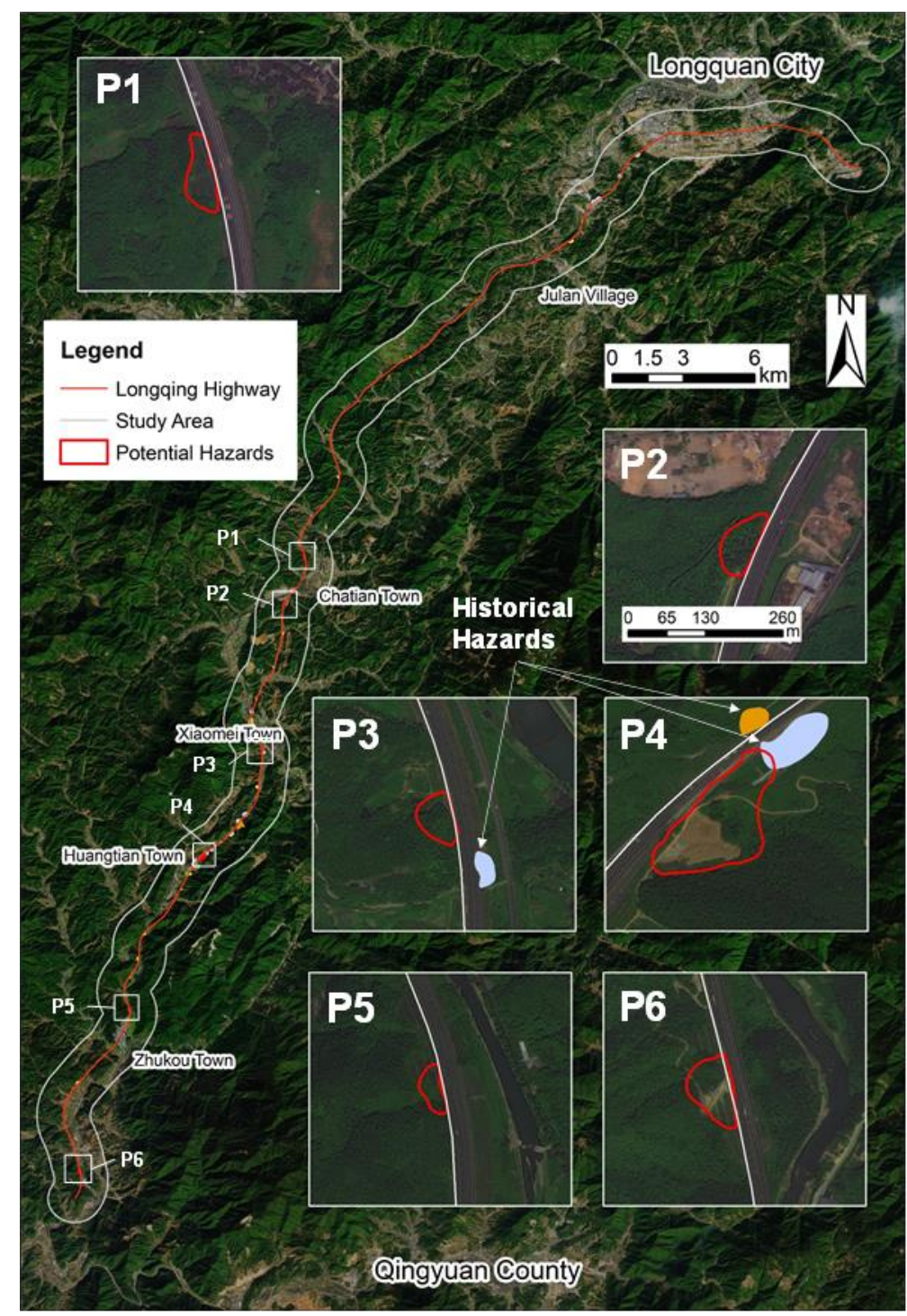

Figure 7. Potential hazards identification based on the combined procedure.
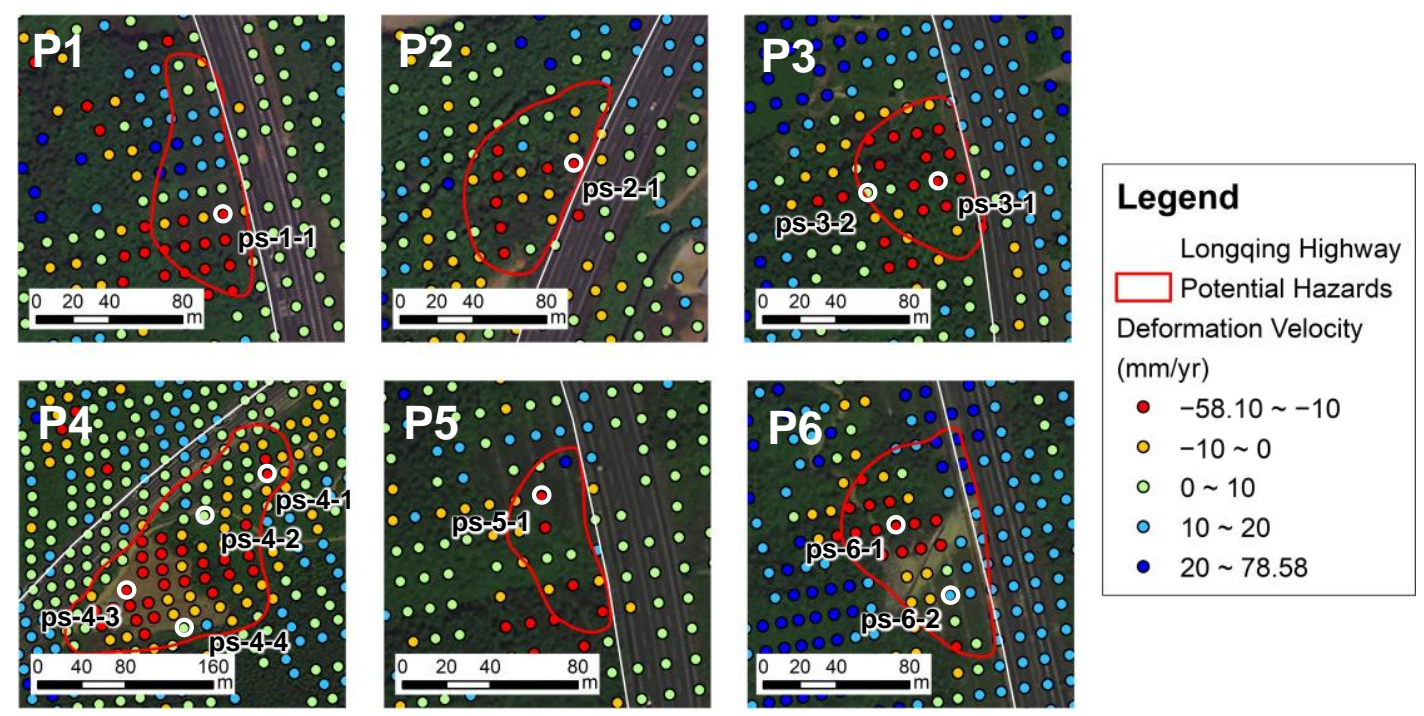

Deformation Velocity $(\mathrm{mm} / \mathrm{yr})$
- $-10 \sim 0$
$0 \sim 10$
$10 \sim 20$
$20 \sim 78.58$

Figure 8. Average deformation velocity map for the identified potential hazards. 

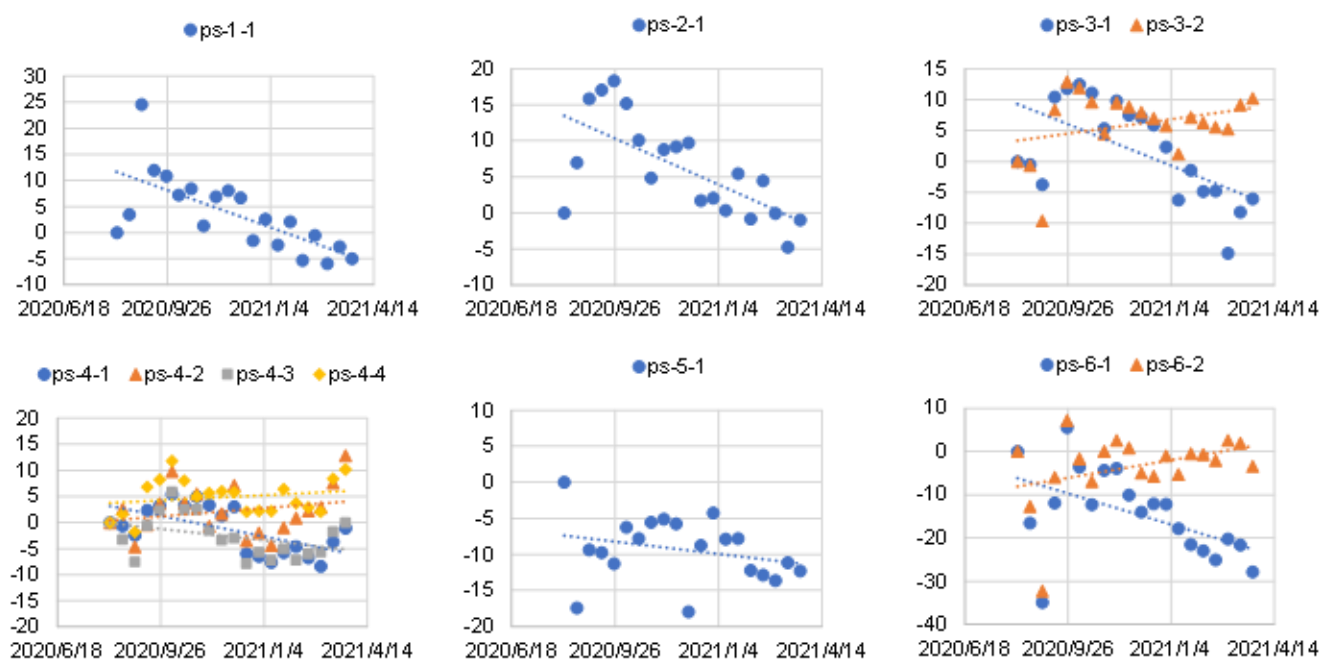

Figure 9. Time-series deformation for selected PS points.

For P4, two obvious abnormal deformation areas can be seen from Figure 8. One area is located on the existing cutting slope (PS points ps-4-1 and ps-4-2), and the other is a bare slope (PS points ps-4-3 and ps-4-4). The overall deformation of this area is not large, but obvious decreasing can be seen of ps-4-1 and ps-4-3 during 7 October to 30 December 2020. Consequently, the LOS deformations for four PS points stay still and begin to increase after 28 February 2021. This is a strange phenomenon and may be explained by the decomposition of ground deformation as following.

As the highway from Chatian to Zhukou is approximately parallel to the azimuth direction of Sentinel-1A satellite, the cutting slope can be classified into two types, i.e., westward slope and eastward slope. Figure 10 illustrates the decomposition of vertical deformation and down-slope deformation for both westward and eastward slopes $[37,38]$. The unit deformation vectors along down-slope or vertical direction and the corresponding projections to the LOS direction for four situations are shown in the figure. Then, the possible movement process can be traced back from the LOS deformation according to Figure 10. According to Figure 7, P1 P3 and P5 P6 are covering the areas of westward slope. In this case, vertical and down-slope deformation are both negative value in LOS direction (away from the satellite) in any slope dip angle. Unlike other slopes, the dip direction of P4 is mainly westward. As ascending orbit data are used in the study, for westward slope, a vertical deformation on the slope always appears to be away from the satellite in the LOS direction (see Figure 10). However, a down-slope deformation can be either close to or away from the satellite when the slope dip angle is larger or smaller than the incidence angle. In terms of P4, the dip angle is around $34^{\circ} \sim 39^{\circ}$ and less than the average incidence angle $43.1^{\circ}$. Thus, the down-slope deformation dominated deformation is positive value in LOS direction. Back to Figure 9, it is suggested that the area may experiences downward movement with decreasing LOS deformation (during 7 October to 30 December 2020) and down-slope movement with increasing LOS deformation (after 28 February 2021).

P6 also shows obvious abnormal deformation areas, which are mainly distributed on the north side of the slope, as shown in Figure 8, with the concrete crest drain ditch as the boundary. It can be observed in Figure 9 that the deformation value of ps-6-2 fluctuates slightly in a small range, but the point ps-6-1 keeps decreasing.

To verify identification results, the field investigation has been carried out from 14 May to 17 May 2021. Typical photographs are presented in Figures 11 and 12 for potential hazards P1 P6. 


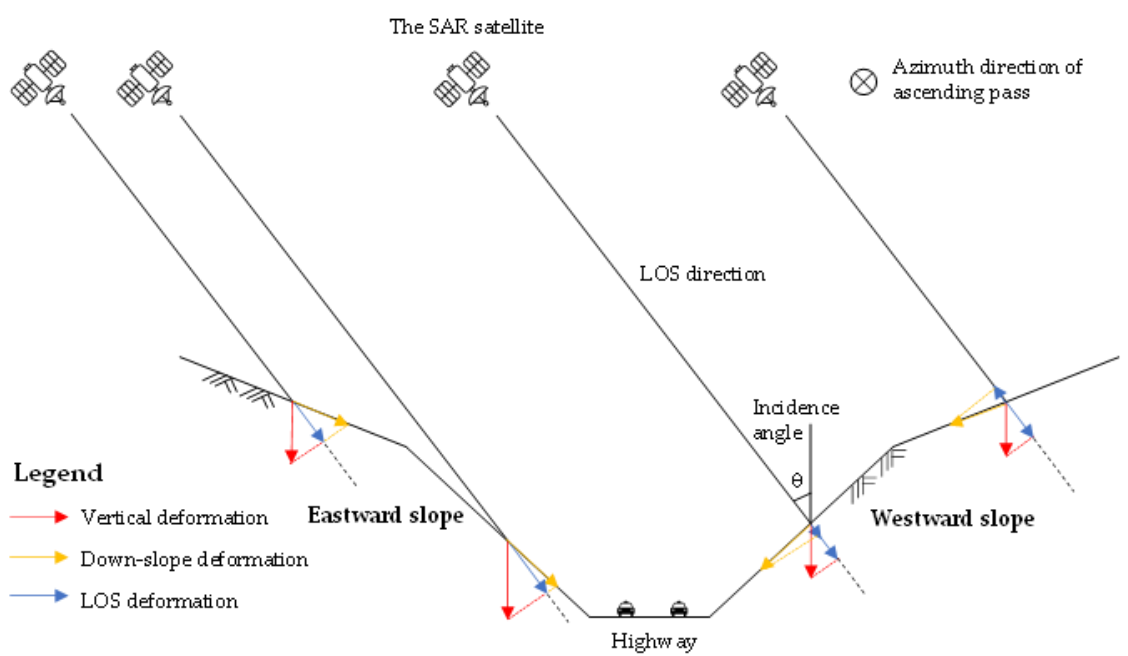

Figure 10. Ground deformation decomposition illustration.
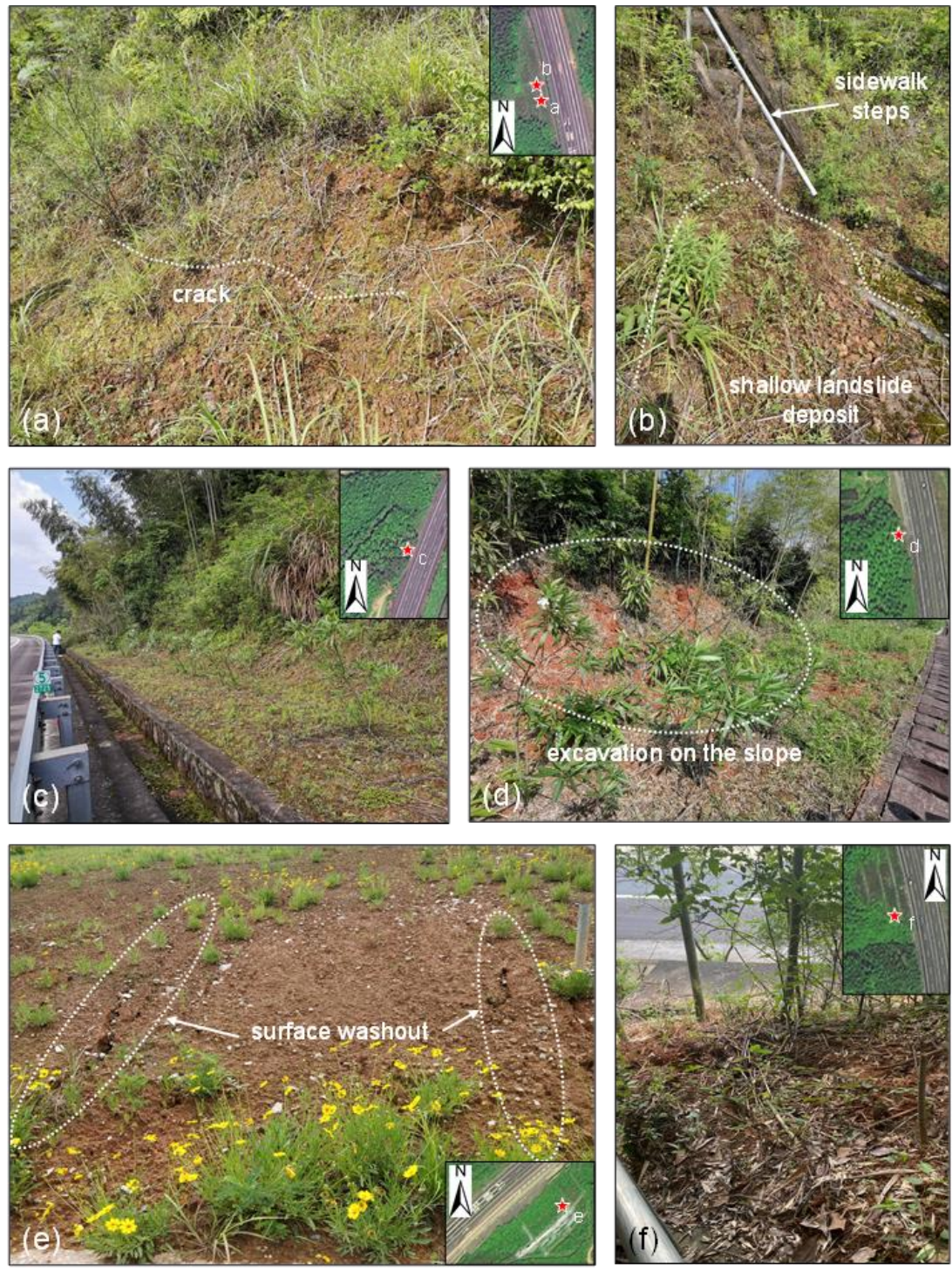

Figure 11. Field validation photographs of potential hazards P1 P5. (a) Joint crack at the 2nd-level slope. (b) Shallow landslide on top of the 2nd-level slope. (c) Full view of P2. (d) Excavation on the slope. (e) Slope surface washout. (f) Vegetation cover on slope. 
Figure 11a show obvious joint cracks on the second-level slope with a width of about $1 \mathrm{~cm}$ and an extension of about $5 \mathrm{~m}$. The cracks are located roughly at the same area where the deformation velocity of InSAR results is the largest. In addition, shallow landslides were also found near the sidewalk (Figure 11b).

From Figure 11c,f, dense vegetation can be seen on the slope for both P2 and P5, but there was no obvious sign of slope deformation or instability. Therefore, the possibility of slope hazards P2 and P5 is ruled out.

Field investigations showed that there were obvious excavation traces on the slope surface (see Figure 11d). Based on consultations from highway maintenance staffs, the slope surface was damaged by artificial excavation around January 2021. It can be indicated that the highway slope deformation identification based on InSAR technology can well reflect the dynamic status of the slope.

Through field survey on P4, it is found that the slope has been well vegetated, and there are local surface washout and cracks on the slope (Figure 11e).
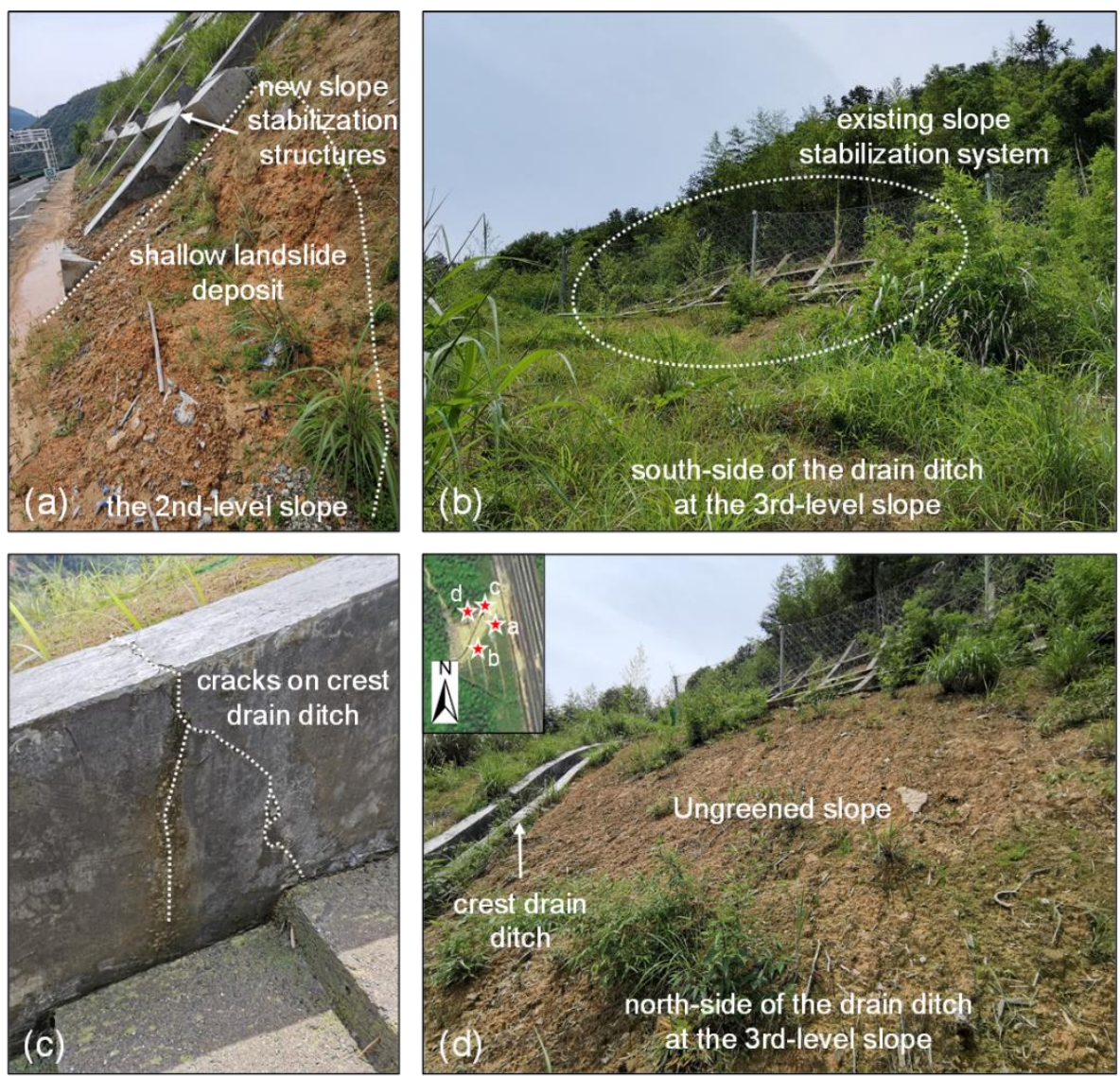

Figure 12. Field validation photographs of potential hazard P6. (a) Shallow landslide on top of the 2nd-level slope. (b) Full view on south-side of drain ditch. (c) Cracks on crest drain ditch. (d) Full view on north-side of drain ditch.

Figure 12 is for potential hazard $\mathrm{P} 6$, and it is reported that the several historical hazards has occurred on the slope. Two slope stabilization systems can be found in Figure 12a,b, and the new structure began to build in 2020 and was finished around August 2020. As described in Figure 8, the crest drain ditch can be the dividing line of area P6, and the southside of the drain ditch is artificially regreened (Figure $12 b$ ), while the vegetation on the north-side is sparsely covered (Figure 12d). It is found that the no vegetation coverage zone is basically consistent with the abnormal deformation area identified by InSAR method. The field investigation also found that there were local shallow landslides (Figure 12a) and cracks on the drain ditch structure (Figure 12c) at the 2nd-level slope. There is a rocky 
layer exposed on the 3rd-level and 4th-level slope, and it has been stabilized by a flexible protection net combined with grid beams (Figure 12b). Since the begin date of the InSAR calculation is just near the completion date of the new slope stabilization structure, it is speculated that the slope deformation may be postconstruction settlement caused by construction disturbance.

\subsection{Feasibility of SBAS-InSAR Technique in Highway Slope Inspection}

SBAS-InSAR technology was used to investigate potential artificial slope hazards along the Longqing Highway. A total of six potential hazards were identified and surveyed manually in the field. The results of InSAR analysis are basically consistent with the on-site verification, which proves that SBAS-InSAR technique can well catch the deformation of slope and reflect the safe status of the slopes.

For slope maintenance inspection, the purpose is to find out potential slope hazards and to limit the risk of slope failure to minimum. According to the Technical Specification for Expressway Slope Maintenance (DB 33/T 2099-2018, a provincial standard of Zhejiang, China) [39] (p. 4) and Guide to Slope Maintenance (Geoguide 5, a recommended standard of Hongkong, China) [40] (p. 53), the routine inspection frequency is normally larger than once per two weeks, as shown in Table 1. Moreover, the entire length of highway should be tested. Thus, the InSAR method can meet the frequency requirement of slope inspection. Taking account of slope safety, the frequency of InSAR inspection can be set as once every 2 months, referring to the abovementioned standards. During the rainy season, the frequency can be adjusted to once or twice every month based on the evolution of deformation and duration/intensity of rainfall. To ensure the quality of results, the time span is recommended to be 6-8 months before each inspection date.

Table 1. Frequency of routine maintenance inspections.

\begin{tabular}{cccc}
\hline $\begin{array}{c}\text { Hongkong Standard } \\
\text { Consequence-to-Life } \\
\text { Category }\end{array}$ & Frequency & Maintenance Grade ${ }^{\mathbf{1}}$ & Frequency \\
\hline $\begin{array}{c}\text { Category } 1 \text { and } 2 \\
\text { Category 3 } \\
\text { Category 3 }\end{array}$ & Once every year & Grade 1 & Once every week \\
located in a remote area ${ }^{2}$ & Once every 2 years & Grade 2 & Once every month \\
\hline${ }^{1}$ React to known hazard & Grade 3 & Once every 2 month \\
\hline
\end{tabular}

${ }^{1}$ Determined based on safety risk classification and traffic volume. ${ }^{2}$ A disturbed terrain feature is in a remote area if it is surrounded by natural terrain such that a failure would bring no significant direct or indirect consequences.

However, there remain several limitations of SBAS-InSAR. As discussed in Figure 10, the orbit track and slope dip influences the deformation detection significantly [38]. In specific cases of slope dip and dip angle, the InSAR method can be insensitive to the deformation. Additionally, most artificial slopes should be regreened after excavation; therefore, high-density coverage of vegetations also reduce the accuracy of InSAR interpretation. In the situation, corner reflector (CR) can be an aid to natural ground objects to supplement PS candidates and to remove the residual topographic phase error [41,42]. From an economic point of view, the cost of SBAS-InSAR method is relatively low, by saving part of the labor input. Nevertheless, the SBAS-InSAR method cannot replace manual inspections in the maintenance of highway, as signs of drainage leakage and cracking on slope surface can be hardly detected by SBAS-InSAR. In addition, the InSAR method has a capability of deformation velocity detection at the level of $\mathrm{mm} / \mathrm{yr}$ to $\mathrm{m} / \mathrm{yr}$; thus, it can be useful for slow to extremely slow slope events rather than fast slope movement. For fast slope movement, approaches with higher monitor frequency should be adopted, such as terrestrial laser scanning (TSL), unmanned aerial vehicles (UAV), ground-based InSAR, and GNSS [21,43].

To summarize, the SBAS-InSAR technique is suitable for assistance in slope routine inspection. 


\section{Conclusions}

In this study, the artificial slopes along Longqing Highway were selected as study object. The SBAS-InSAR technique was applied to obtain the ground deformation of $1 \mathrm{~km}$ buffer area along the highway. Potential hazards were detected based on deformation abnormal area preliminarily and then filtered by terrain, geological, and historical hazards data. Field verification study was then conducted for the identification results, and the feasibility of SBAS-InSAR technique in highway slope inspection was analyzed.

The results show that the identified potential slope hazards are mainly distributed to the south of Chatian Town, where the granite residual layer and the Quaternary soil layer are widely distributed. It is in good consistence with the areas of historical hazards. Six slope potential hazards were identified based on slope terrain, geological data, and historical hazard record. The interpretation of InSAR basically accord with the on-site verification. It is proved that SBAS-InSAR technique can well catch the deformation of slope and reflect the safe status of the slopes. Finally, the SBAS-InSAR technique can be suitable for assistance in slope routine inspection.

Author Contributions: Conceptualization, W.Z. and Z.H.; methodology, Z.H. and D.X.; software, Z.H. and Y.Y. (Yang Yu); validation, Y.Y. (Yiqiang Yu), Y.Y. (Yang Yu), and C.P.; formal analysis, X.Y. and Z.H.; investigation, Z.H.; writing-original draft preparation, Z.H.; writing-review and editing, W.Z.; funding acquisition, W.Z. All authors have read and agreed to the published version of the manuscript.

Funding: This research was funded by National Key R\&D Program of China, grant number 2020YFC1512005 and Science and Technology Project of Zhejiang Provincial Department of Transport, grant number 2020051.

Institutional Review Board Statement: Not applicable.

Data Availability Statement: The data presented in this study are available on request from the corresponding author.

Acknowledgments: The workflow between SNAP and StaMPS was performed with significant support from open-access code snap2stamp_sbas by Yusen Dong from China University of Geosciences. The authors are grateful to Xin Yao and his PhD candidates Zhenkai Zhou and Yifei Zhu from Institute of Geomechanics, Chinese Academy of Geological Sciences, for the consultant during the implementation of InSAR method.

Conflicts of Interest: The authors declare no conflict of interest.

\section{References}

1. Ding, Y.; Wang, P.; Liu, X.; Zhang, X.; Hong, L.; Cao, Z. Risk assessment of highway structures in natural disaster for the property insurance. Nat. Hazards 2020, 104, 2663-2685. [CrossRef]

2. Zaki, A.; Chai, H.K.; Razak, H.A.; Shiotani, T. Monitoring and evaluating the stability of soil slopes: A review on various available methods and feasibility of acoustic emission technique. Comptes Rendus Geosci. 2014, 346, 223-232. [CrossRef]

3. Liang, H.; Li, X.; Zhang, L.; Chen, R.-F.; Ding, X.; Chen, K.-L.; Wang, C.-S.; Chang, C.-S.; Chi, C.-Y. Investigation of slow-moving artificial slope failure with multi-temporal InSAR by combining persistent and distributed scatterers: A case study in Northern Taiwan. Remote Sens. 2020, 12, 2403. [CrossRef]

4. Aimaiti, Y.; Yamazaki, F.; Liu, W.; Kasimu, A. Monitoring of land-surface deformation in the Karamay Oilfield, Xinjiang, China, using SAR interferometry. Appl. Sci. 2017, 7, 772. [CrossRef]

5. Aslan, G.; Cakır, Z.; Ergintav, S.; Lasserre, C.; Renard, F. Analysis of secular ground motions in Istanbul from a long-term InSAR time-series (1992-2017). Remote Sens. 2018, 10, 408. [CrossRef]

6. Zhao, F.; Meng, X.; Zhang, Y.; Chen, G.; Su, X.; Yue, D. Landslide susceptibility mapping of Karakorum highway combined with the application of SBAS-InSAR technology. Sensors 2019, 19, 2685. [CrossRef]

7. Luo, Q.; Perissin, D.; Zhang, Y.; Jia, Y. L- and X-band multi-temporal InSAR analysis of Tianjin subsidence. Remote Sens. 2014, 6, 7933-7951. [CrossRef]

8. Xing, X.; Chang, H.-C.; Chen, L.; Zhang, J.; Yuan, Z.; Shi, Z. Radar interferometry time series to investigate deformation of soft clay subgrade settlement-A case study of Lungui Highway, China. Remote Sens. 2019, 11, 429. [CrossRef]

9. Jefriza; Yusoff, I.M.; Abir, I.A.; Syahreza, S.; Rusdi, M.; Razi, P.; Lateh, H. The applications of InSAR technique for natural hazard detection in smart society. J. Phys. Conf. Ser. 2020, 1572, 012067. [CrossRef] 
10. Qin, Y.; Hoppe, E.; Perissin, D. Slope hazard monitoring using high-resolution satellite remote sensing: Lessons learned from a case study. ISPRS Int. J. Geo-Inf. 2020, 9, 131. [CrossRef]

11. Zhu, K.; Xu, P.; Cao, C.; Zheng, L.; Liu, Y.; Dong, X. Preliminary identification of geological hazards from songpinggou to feihong in Mao county along the Minjiang river using SBAS-InSAR technique integrated multiple spatial analysis methods. Sustainability 2021, 13, 1017. [CrossRef]

12. Zhuo, G.; Dai, K.; Huang, H.; Li, S.; Shi, X.; Feng, Y.; Li, T.; Dong, X.; Deng, J. Evaluating potential ground subsidence geo-hazard of Xiamen Xiang'an new airport on reclaimed land by SAR Interferometry. Sustainability 2020, 12, 6991. [CrossRef]

13. Casagli, N.; Bianchini, S.; Ciampalini, A.; Del Soldato, M.; Ezquierro, P.; Montalti, R.; Shan, M.; Solari, L.; Raspini, F. Sentinel-1 InSAR data for the continuous monitoring of ground deformation and infrastructures at regional scale. In Advances in Remote Sensing for Infrastructure Monitoring; Springer: Cham, Switzerland, 2020; pp. 63-80. [CrossRef]

14. Hayati, N.; Niemeier, W.; Sadarviana, V. Ground deformation in the Ciloto landslides area revealed by multi-temporal InSAR. Geosciences 2020, 10, 156. [CrossRef]

15. He, Y.; Chen, Y.; Wang, W.; Yan, H.; Zhang, L.; Liu, T. Ts-Insar analysis for monitoring ground deformation in Lanzhou new district, the loess plateau of China, from 2017 to 2019. Adv. Space Res. 2021, 67, 1267-1283. [CrossRef]

16. Ramirez, R.; Lee, S.-R.; Kwon, T.-H. Long-term remote monitoring of ground deformation using sentinel-1 interferometric Synthetic Aperture Radar (InSAR): Applications and insights into geotechnical engineering practices. Appl. Sci. 2020, 10, 7447. [CrossRef]

17. Wang, Y.; Guo, Y.; Hu, S.; Li, Y.; Wang, J.; Liu, X.; Wang, L. Ground deformation analysis using InSAR and backpropagation prediction with influencing factors in Erhai region, China. Sustainability 2019, 11, 2853. [CrossRef]

18. D'Amico, F.; Gagliardi, V.; Ciampoli, L.B.; Tosti, F. Integration of InSAR and GPR techniques for monitoring transition areas in railway bridges. NDT E Int. 2020, 115, 102291. [CrossRef]

19. Zhang, L.; Sun, Q.; Hu, J. Potential of TCPInSAR in monitoring linear infrastructure with a small dataset of SAR images: Application of the Donghai Bridge, China. Appl. Sci. 2018, 8, 425. [CrossRef]

20. Wu, W.; Cui, H.; Hu, J.; Yao, L. Detection and 3d visualization of deformations for high-rise buildings in Shenzhen, China from high-resolution TerrasSAR-X datasets. Appl. Sci. 2019, 9, 3818. [CrossRef]

21. Dai, K.; Li, Z.; Xu, Q.; Burgmann, R.; Milledge, D.G.; Tomas, R.; Fan, X.; Zhao, C.; Liu, X.; Peng, J.; et al. Entering the era of Earth observation-based landslide warning systems: A novel and exciting framework. IEEE Geosci. Remote Sens. Mag. 2020, 8, 136-153. [CrossRef]

22. Azadnejad, S.; Maghsoudi, Y.; Perissin, D. Evaluation of polarimetric capabilities of dual polarized sentinel-1 and TerraSAR-X data to improve the psinsar algorithm using amplitude dispersion index optimization. Int. J. Appl. Earth Obs. Geoinform. 2020, 84, 101950. [CrossRef]

23. Cigna, F.; Bianchini, S.; Casagli, N. How to assess landslide activity and intensity with Persistent Scatterer Interferometry (PSI): The PSI-based matrix approach. Landslides 2012, 10, 267-283. [CrossRef]

24. Fiaschi, S.; Holohan, E.; Sheehy, M.; Floris, M. Ps-InSAR analysis of sentinel-1 data for detecting ground motion in temperate oceanic climate zones: A case study in the republic of Ireland. Remote Sens. 2019, 11, 348. [CrossRef]

25. Fryksten, J.; Nilfouroushan, F. Analysis of clay-induced land subsidence in Uppsala city using sentinel-1 SAR data and precise leveling. Remote Sens. 2019, 11, 2764. [CrossRef]

26. Dong, S.; Samsonov, S.; Yin, H.; Ye, S.; Cao, Y. Time-series analysis of subsidence associated with rapid urbanization in Shanghai, China measured with SBAS InSAR method. Environ. Earth Sci. 2013, 72, 677-691. [CrossRef]

27. Hu, B.; Wang, H.-S.; Sun, Y.-L.; Hou, J.-G.; Liang, J. Long-term land subsidence monitoring of Beijing (China) using the Small Baseline Subset (SBAS) technique. Remote Sens. 2014, 6, 3648-3661. [CrossRef]

28. Yalvac, S. Validating InSAR-SBAS results by means of different GNSS analysis techniques in medium- and high-grade deformation areas. Environ. Monit. Assess. 2020, 192, 120. [CrossRef]

29. Zhang, Y.; Liu, Y.; Jin, M.; Jing, Y.; Liu, Y.; Liu, Y.; Sun, W.; Wei, J.; Chen, Y. Monitoring land subsidence in Wuhan city (China) using the Sbas-InSAR method with radarsat-2 imagery data. Sensors 2019, 19, 743. [CrossRef] [PubMed]

30. Berardino, P.; Fornaro, G.; Lanari, R.; Sansosti, E. A new algorithm for surface deformation monitoring based on small baseline differential SAR interferograms. IEEE Trans. Geosci. Remote Sens. 2002, 40, 2375-2383. [CrossRef]

31. Bayer, B.; Simoni, A.; Schmidt, D.; Bertello, L. Using advanced InSAR techniques to monitor landslide deformations induced by tunneling in the Northern Apennines, Italy. Eng. Geol. 2017, 226, 20-32. [CrossRef]

32. Zhu, Y.; Xing, X.; Chen, L.; Yuan, Z.; Tang, P. Ground subsidence investigation in Fuoshan, China, based on SBAS-InSAR technology with TerraSAR-X images. Appl. Sci. 2019, 9, 2038. [CrossRef]

33. Foumelis, M.; Blasco, J.M.D.; Desnos, Y.-L.; Engdahl, M.; Fernandez, D.; Veci, L.; Lu, J.; Wong, C. ESA SNAP—StaMPS integrated processing for sentinel-1 persistent scatterer interferometry. In Proceedings of the IEEE International Geoscience and Remote Sensing Symposium, Valencia, Spain, 22-27 July 2018; pp. 1364-1367.

34. Mancini, F.; Grassi, F.; Cenni, N. A workflow based on SNAP-StaMPS open-source tools and GNSS data for PSI-Based ground deformation using dual-orbit sentinel-1 data: Accuracy assessment with error propagation analysis. Remote Sens. 2021, 13, 753. [CrossRef]

35. Delgado Blasco, J.; Foumelis, M.; Stewart, C.; Hooper, A. Measuring urban subsidence in the Rome metropolitan area (Italy) with sentinel-1 SNAP-StaMPS persistent scatterer interferometry. Remote Sens. 2019, 11, 129. [CrossRef] 
36. Du, Y.; Feng, G.; Li, Z.; Peng, X.; Zhu, J.; Ren, Z. Effects of external digital elevation model inaccuracy on StaMPS-PS processing: A case study in Shenzhen, China. Remote Sens. 2017, 9, 1115. [CrossRef]

37. Fan, H.; Wang, L.; Wen, B.; Du, S. A new model for three-dimensional deformation extraction with single-track InSAR based on mining subsidence characteristics. Int. J. Appl. Earth Obs. Geoinform. 2020, 94, 102223. [CrossRef]

38. Power, D.; Youden, J.; English, J.; Russell, K.; Croshaw, S.; Hanson, R. InSAR Applications for Highway Transportation Projects, Federal Highway Administration, Central Federal Lands Highway Division: Washington, DC, USA, 2006.

39. Zhejiang Provincial Bureau of Quality and Technical Supervision. Technical Specification for Expressway Slope Maintenance (DB 33/T 2099-2018); Zhejiang Provincial Bureau of Quality and Technical Supervision: Hangzhou, China, 2018.

40. GEO. Guide to Slope Maintenance. Geoguide 5, 3rd ed.; Continuously Updated E-Version Released on 20 November 2018; Geotechnical Engineering Office: Hong Kong, China, 2018.

41. Zhu, W.; Zhang, Q.; Ding, X.; Zhao, C.; Yang, C.; Qu, F.; Qu, W. Landslide monitoring by combining of CR-InSAR and GPS techniques. Adv. Space Res. 2014, 53, 430-439. [CrossRef]

42. Bovenga, F.; Pasquariello, G.; Pellicani, R.; Refice, A.; Spilotro, G. Landslide monitoring for risk mitigation by using corner reflector and satellite SAR interferometry: The large landslide of Carlantino (Italy). Catena 2017, 151, 49-62. [CrossRef]

43. Huggel, C.; Frey, H.; Klimeš, J.; Strozzi, T.; Caduff, R.; Cochachin, A. Contribution of Earth Observation to Landslide Early Warning; University of Zurich: Zürich, Switzerland; Gamma Remote Sensing: Muri near Bern, Switzerland; National Wateri Authority of Peru: San Isidro, Peru, 2017. Available online: http://www.geo.uzh.ch/ \{\}chuggel/files_download/alcantara/eo_ews_white_ paper_esa_alcantara_2017.pdf (accessed on 13 September 2021). 